\title{
Papers
}

\section{Building depreciation and sustainable development}

Received (in revised form): 18th April, 2007

\section{Chung Yim Yiu}

is currently an assistant professor in the Department of Real Estate and Construction, the University of Hong Kong. $\mathrm{He}$ is a qualified building surveyor, and a corporate member of the Royal Institute of Chartered Surveyors and the Hong Kong Institute of Surveyors. His research interests and expertise are in building maintenance, property and construction economics, and finance.

Correspondence: Chung Yim Yiu, Department of Real Estate and Construction, The University of Hong Kong, Pokfulam, Hong Kong; Tel: (852) 2219 4154; Fax: (852) 2559 9457; E-mail: ecyyiu@hkucc.hku.hk

\begin{abstract}
Sustainable development is a hot topic, but is mostly referred to environmental protection, although it encompasses environmental, social and economic developments as defined by the United Nations. Worse still, the impacts of building maintenance on sustainable (economic) development are almost totally ignored. This paper aims to carry out the first sensitivity analysis of the impacts of housing depreciation on sustainable development in Hong Kong. The analysis is based on an empirical result of the housing depreciation rate and an estimation of the ageing trend of housing in Hong Kong. The results highlight the utmost importance of building maintenance on achieving sustainable development. It does not only reduce construction waste, but it also enhances the total asset value of the city. For example, the analysis shows that a 10 per cent reduction of housing depreciation would yield about 14 per cent increase in gross domestic product (GDP) in a decade, but it just costs about 2.3 per cent of GDP.
\end{abstract}

Journal of Building Appraisal (2007) 3, 97-103. doi:10.1057/palgrave.jba.2950072

\section{Keywords:}

sustainable development, housing depreciation, sensitive analysis

\section{INTRODUCTION}

The importance of building maintenance is seriously ignored among building owners as well as governments. Their ignorance cannot be denied in the light of the dilapidation and deterioration of buildings in various parts of the world. The situation is similar to the pollution problem in the 1980s when people could not have cared less about the environment. With efforts and resources from various organisations, and especially through the promotion of sustainability by the United Nations since 1987, environmental protection has, however, achieved great success, although there is still much to be desired. Nowadays, the importance of environmental protection has been highly recognised and reflected in the commitment and the actual performance of the world as a whole. To the contrary, unfortunately, building maintenance is not commonly regarded when sustainable development issues are discussed. Very often, sustainability is perceived as something related to environmental issues. 
United Nations (2002), however, contended that sustainable development shall be defined by encompassing economic, environmental and social development. The most fundamental idea of sustainability is to sustain 'development which meets the needs of the present without compromising the ability of future generations to meet their own needs' (WCED, 1987). Yet, building deterioration will inevitably result in higher economic loss, more environmental waste and poorer social living conditions. Similar to environmental protection, building maintenance requires the efforts and resources of the present generation, but the benefits will only be realised by future generations. As is the case with pollution problems, building owners would not invest optimally on building maintenance as the economic cost of building deterioration is shared with the society at large.

This paper aims to study the importance of building durability on sustainable development. A case study on the housing stock in Hong Kong was exploited to illustrate the impact of building depreciation on sustainable economic development. A sensitivity analysis was then carried out to show the effects. The analysis was conducted based on data of the ageing trend of housing and the estimation of housing depreciation rate in Hong Kong studied by the author previously.

\section{BACKGROUND}

The built environment is certainly one of the dominant stakeholders of sustainable development. A large number of studies on the contribution of the built environment to sustainable development have been conducted; however, very few discuss the impact of 'building maintenance' on sustainability. Most studies focus on new designs that encourage more efficient use of natural resources, deliver pollution free and ecologically supportive urban landscape. When economic development is addressed, most focused on the increase of property value by these new designs. Unfortunately, there is very little discussion on the contribution of maintenance of existing buildings to sustainable development and those exceptions focused on environmental issues only. For example, Jones and Clements-Croome (2004) posited that refurbishment of derelict properties could reduce demolition and construction waste while Pearce et al. (1996) contended that repairing existing structures would save a lot of materials and resources.

In Atkinson et al.'s (1997) 'Models for measuring sustainable development', they explicitly considered depreciation value of produced assets in measuring genuine savings of development. Mathematically,

$$
S_{g}=G N P-C-D-n(R-g)-\sigma(e-d)
$$

where $S_{g}$ is the genuine saving, GNP is the gross national products, $C$ is the sum of public and private consumptions (ie $G N P-C$ represents the gross saving), $D$ is the value of depreciation of produced assets and the last two terms are the net depletion cost of natural resources and the net cost of pollutants accumulation. Equation (1) clearly spells out the crucial role of reducing depreciation in achieving a more sustainable development by increasing genuine savings. Unfortunately, their empirical studies extracted depreciation data from the United Nations (1992) of the National Accounts Statistics, which is a very rough estimation of depreciation values for accounting purpose. In line with accounting principles, depreciation is usually 'calculated by allocating the costs of past expenditures on fixed assets over subsequent accounting periods' (United Nations, 2007). Indeed, depreciation value is commonly regarded as a conceptual idea which is hard to observe in real life, especially when inflation or deflation is serious. Taking a typical real estate 
investment 40 years ago in Hong Kong, for example, the nominal price growth of the real estate investment might be as high as 1,500 per cent, which disguised strongly any depreciation value in the assets when compared with its cost. Such general appreciation of asset value in real estate markets renders the ignorance of depreciation value in the agenda of sustainable development. Thus, asset depreciation shall be measured by an 'all other things being equal' approach, as Hulten and Wykoff (1981) defined 'economic depreciation as the decline of asset price due to aging'.

\section{AGEING TREND OF HOUSING IN HONG KONG}

Hong Kong is well known for its high density development and of high land value. Its land area is approximately $1,100 \mathrm{~km}^{2}$, but there were more than seven million citizens recorded in 2006 . The population density is 6,420 people per square kilometre on average and reached 50,910 people per square kilometre in the most densely populated district as of mid-2005 (Hong Kong Government, 2006). High-rise buildings of about 20-50 storeys are the norm for housing developments in Hong Kong. There were about 31,300 blocks of private housing consisting of $1,053,246$ units at the end of 2005. Each year about 24,600 units have been newly completed over the past decade. Figure 1 shows the trend for the number of housing apartment units and their annual completion in Hong Kong from 1937 to 2006.

Private housing wealth represents a very large portion of capital investment, and is probably the dominant asset wealth of individuals in Hong Kong and at the end of 2005 was estimated at HK\$2.7tn (US\$0.35tn). Although it was just about one-sixtieth of that in the US, it was equivalent to about twice that of the gross domestic product (GDP) of Hong Kong (US\$0.18tn), more than 50 per cent of the total deposits in banking institutions (US\$0.52tn) or about 33 per cent of the total market capitalisation value of the stock exchange market (US\$1.04tn). The housing market is undeniably one of the major components of the city wealth. The ageing, or more precisely the depreciation, of the asset is a drain of the wealth, which would seriously hinder the sustainable development

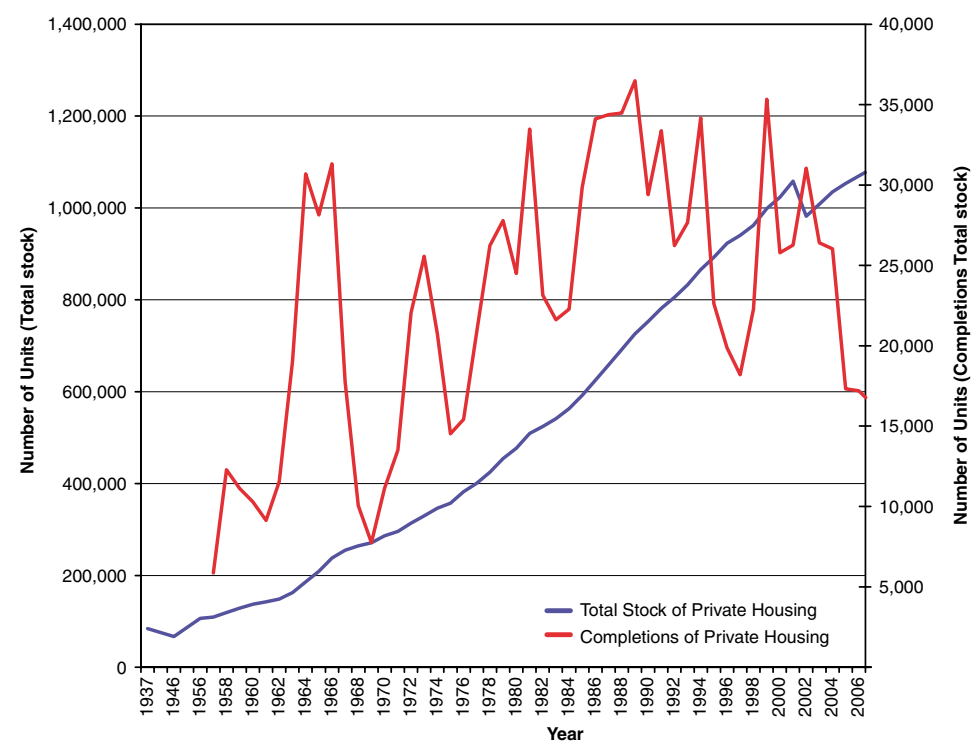

Figure I: Growing trend of private housing units and their completion in Hong Kong 1937-2006 Source: Rating and Valuation Department (various issues)

Notes: Excludes Public Rental Housing, Subsidised Housing, Village Houses, Temporary Houses etc. The sudden drop in 2002 was due to the exclusion of village houses in the statistics since 2002 
of the city. Worse still, more than 20 per cent of the private housing wealth is financed by mortgages (ie total outstanding mortgage loans for private housing amounted to $\mathrm{HK} \$ 0.53 \mathrm{tn}$ at the end of 2005), thus any aggravating trend of depreciation of housing would jeopardise the risk management of financial institutions.

Unfortunately, the city is ageing rapidly in both the population and the housing asset. Figures 2 and 3 show the ageing trends of the population since 1996 and the ageing trend of housing asset over the past 40 years and its projection to 2016. Currently, more than one-third of the building stock in the city is more than 30 years old. Interestingly, only the alarming ageing population attracts the government's attention when economic and social development

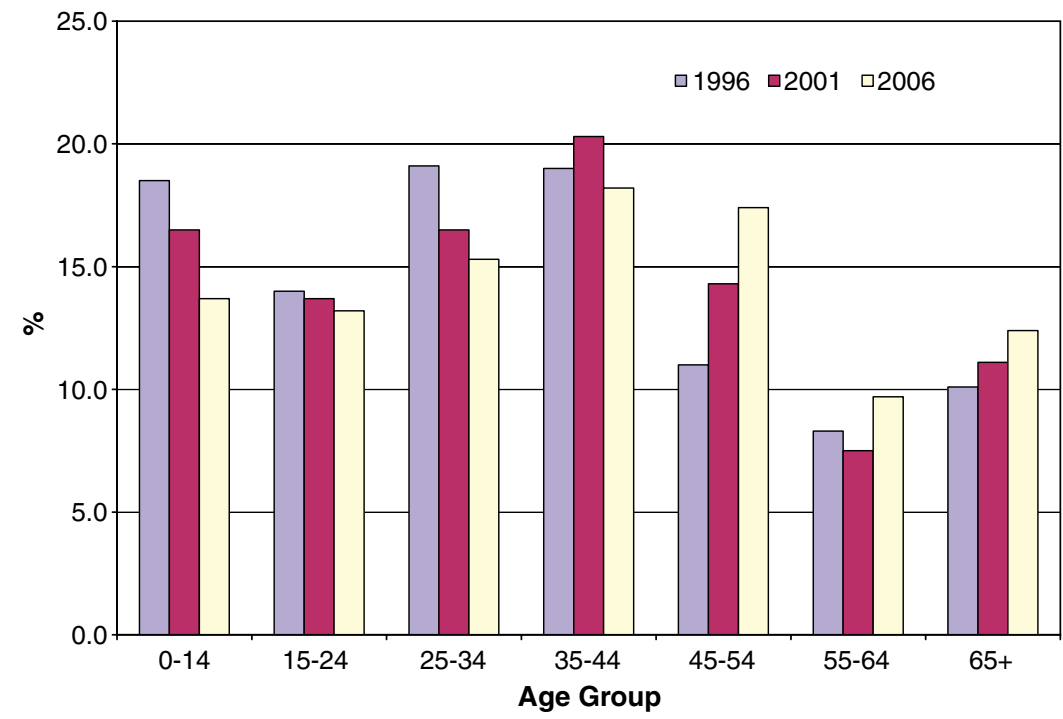

Figure 2: Ageing population in Hong Kong, 1996, 200I and 2006 Source: Census and Statistics Department (2007)

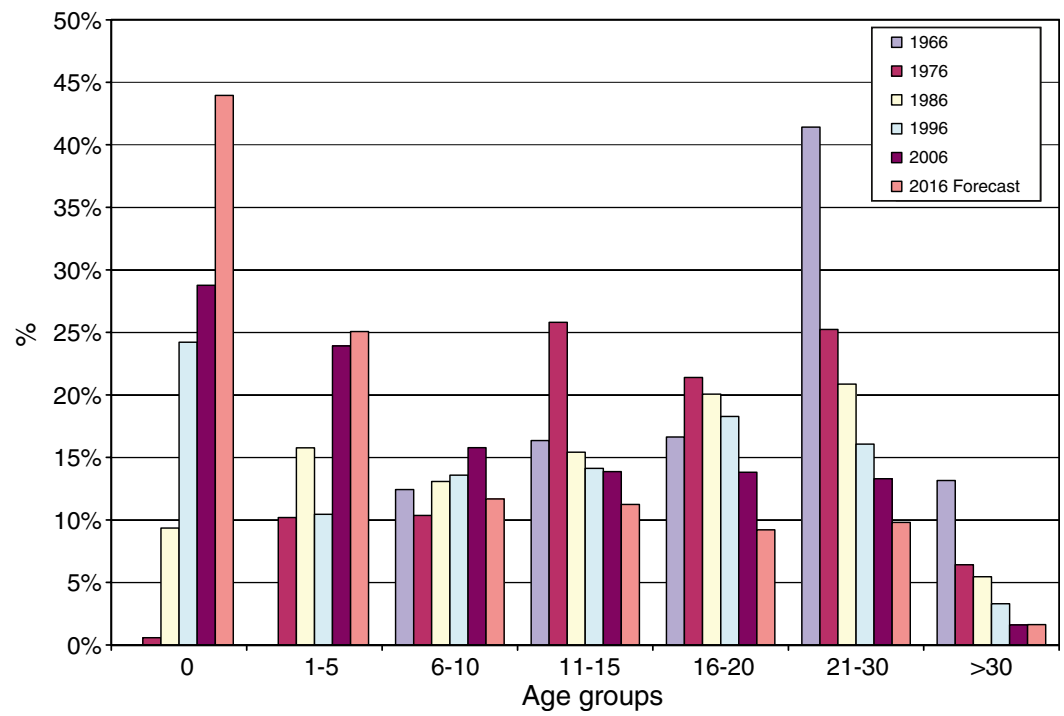

Figure 3: Ageing housing units in Hong Kong, 1966-2016

Source: Estimated and forecasted by data from Rating and Valuation Department (various issues) 
of Hong Kong in the future is concerned. The loss of wealth due to building depreciation has never been heard in the government's discussion of sustainable development.

\section{ESTIMATION OF THE HOUSING DEPRECIATION RATE}

Instead of relying on the depreciation estimation methods by accountants, actual depreciation value of housing can be observed and measured empirically by a crosssectional hedonic pricing model, provided that all other factors can be kept as equal. It is not easy but it is methodologically possible. The hedonic pricing model has been intensively adopted in real estate studies (the latest review by Sirmans et al., 2005), which basically exploits the regression method to investigate the effects of individual factors on the housing price. Thus, the market depreciation rate of housing assets can be identified by incorporating building age-related variables into the hedonic pricing model. There have been many hedonic studies on building depreciation. Some found linear depreciation rates (Hulten and Wykoff, 1981; Malpezzi et al., 1987; Wykoff, 1989), while others found nonlinear ones (Chinloy, 1977; Shilling et al., 1991; Yiu, 2002).

We conducted a similar hedonic pricing analysis in one of the largest housing estates in Hong Kong: the Mei Foo Sun Chuen (MFSC). The sample estate provides an excellent data set for the study of housing depreciation rate as it provides a large sample size with a very high variety of housing ages across the estate. There are more than 100 blocks of 20-storey high buildings that were about $30-40$ years old in 2007 . They are very actively transacted as there are more than 29,000 valid transactions since 1969 . The estate is one of the bestmanaged housing estates in Hong Kong, thus the estimated depreciation rate below is an underestimate of that of housing of the territory as a whole. The hedonic model controls the effects of all other factors, including inflation and building characteristics such as size and height. The continuous line in Figure 4 plots the estimated market depreciation rate of the housing in this estate with all other things being equal. It shows that a 40 -year-old housing flat in the estate had depreciated about 45 per cent of its value in comparison with a newly completed one. This figure reflects the market participants' pricing on different aged assets as their estimations are based on actual transaction prices. Keeping this depreciation rate

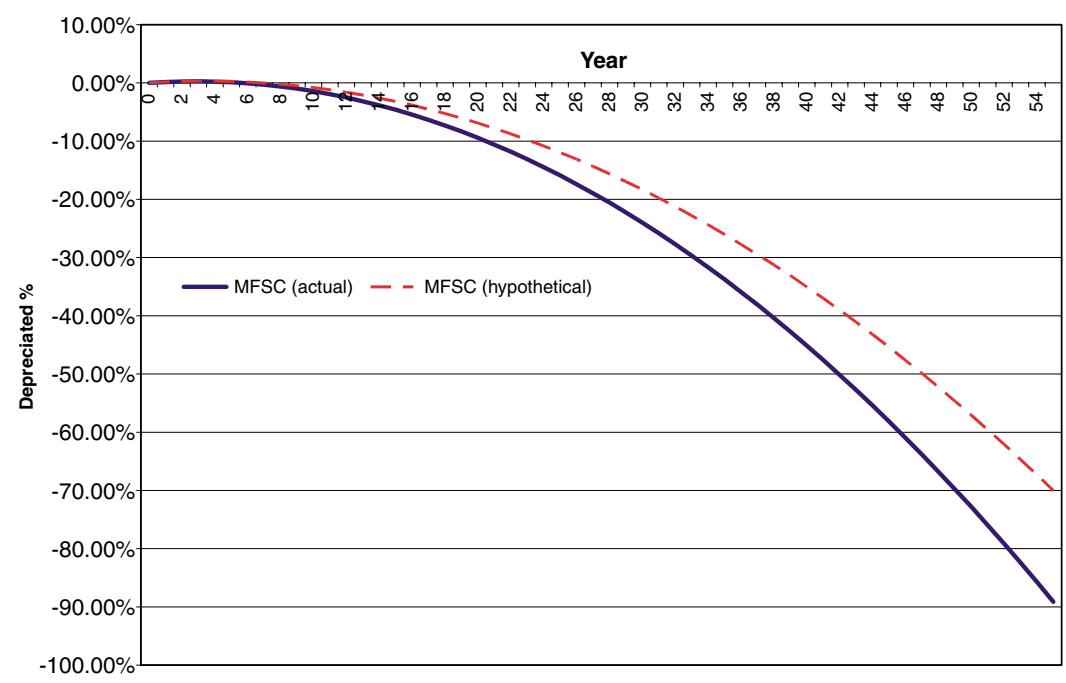

Figure 4: Depreciation rates of housing in MFSC, Hong Kong. Cross-section study in 1991-2004 Transactions

Source: author's estimates 
Table I: Losses due to depreciation in HK as a whole in a decade, 2005-20I5

\begin{tabular}{|c|c|c|c|c|c|c|c|c|}
\hline Year & Age & $>45$ & $35-45$ & $25-35$ & $15-25$ & $5-15$ & $0-5$ & $\begin{array}{l}\text { Total (HKS } \\
\text { billion) }\end{array}$ \\
\hline \multirow[t]{2}{*}{2005} & $\begin{array}{l}\% \text { of stock } \\
\text { Depreciated } \\
\text { unit price }\end{array}$ & $\begin{array}{r}3.70 \\
456.88\end{array}$ & $\begin{array}{r}14.60 \\
2,304.29\end{array}$ & $\begin{array}{r}18.40 \\
3,191.50\end{array}$ & $\begin{array}{r}26.30 \\
3,803.18\end{array}$ & $\begin{array}{r}22.90 \\
4,139.35\end{array}$ & $\begin{array}{r}14.10 \\
4,200.00\end{array}$ & $100.00 \%$ \\
\hline & $\begin{array}{l}\text { Asset value } \\
\text { Age }\end{array}$ & $\begin{array}{l}13.35 \\
>45\end{array}$ & $\begin{array}{l}265.75 \\
35-45\end{array}$ & $\begin{array}{l}463.88 \\
25-35\end{array}$ & $\begin{array}{l}790.12 \\
15-25\end{array}$ & $\begin{array}{l}748.79 \\
10-15\end{array}$ & 467.80 & $2,749.69$ \\
\hline \multirow[t]{3}{*}{2015} & $\%$ of stock & 9.65 & 14.08 & 20.23 & 25.07 & 11.24 & $\begin{array}{l}\text { New Buildings } \\
\text { After } 2006 \text { (not counted) }\end{array}$ & $80.27 \%$ \\
\hline & $\begin{array}{l}\text { Depreciated } \\
\text { unit price }\end{array}$ & 456.88 & $2,304.29$ & $3,191.50$ & $3,803.18$ & $4,139.35$ & & $2,270.85$ \\
\hline & Asset value & 41.15 & 302.83 & 602.64 & 889.95 & 434.27 & & \\
\hline \multicolumn{8}{|c|}{ Loss due to depreciation (HK $\$$ billion) } & 478.84 \\
\hline
\end{tabular}

unchanged for another decade, Table 1 shows that, just in the housing sector, our society would have to pay about HK $\$ 479$ bn for nothing but drained away by depreciation. It amounts to about 34 per cent of our GDP of Hong Kong in 2005.

In the past few decades, we do not care about depreciation as new developments were so excessive that asset 'drain-in' exceeded 'drain-out'. With the depletion of the developable land, however, new developments have been sharply decreasing. We are facing a scenario of net drain-out in the coming decades. The question raised by this paper is how much more genuine savings our society can achieve if our housing stock depreciates a bit slower? The dotted line in Figure 4 plots a hypothetical depreciation rate curve by reducing 10 per cent at the point of 40-year of the market rate curve.

\section{HOUSING DEPRECIATION AND SUSTAINABLE DEVELOPMENT}

Table 2 shows a sensitivity analysis of the genuine saving by reducing the housing depreciation rate. It shows that simply by reducing the depreciation rate by 10 per cent at 40 -year-old housing, it saves about HK\$200bn in a decade (it is about 14 per cent of GDP of Hong Kong in 2005). It is estimated that such a reduction in depreciation rate can be achieved by injecting about $\mathrm{HK} \$ 32.2 \mathrm{bn}$ to maintain all the housing units in the city for a decade. In other words, the net saving amounts to about HK\$167.8bn in a decade.

This analysis implies that building appraisal and maintenance are of paramount importance, not just for the benefits of the owners, but for a more sustainable economic development. Building appraisal is therefore not just an exercise for defects detection and diagnosis, but a necessary step towards sustainability. Building pathology shall be evaluated from the sustainable development perspective. It is therefore recommended to report actual depreciation rates of real estate annually and globally, so as to benchmark and assess the contributions of building pathology towards sustainability.

\section{CONCLUSIONS}

Physical assets, including real estate, depreciate over time, but their depreciation rate is not fixed. A high depreciation rate implies faster drains of our resources, which works against the idea of sustainable development. Unfortunately, depreciation is seldom discussed in the agenda of sustainability. Admittedly, actual depreciation rates of assets are hard to observe as they are inextricably intertwined with many other factors, including inflation. This paper attempts to estimate the actual depreciation rate of housing in Hong Kong by an 'all other things being equal' approach. The analysis implies that building 
Table 2: Sensitivity analysis on losses due to depreciation

\begin{tabular}{lc}
\hline & Value (HKS billion) \\
\hline Private domestic real estate value in 2005 & $2,749.69$ \\
Private domestic real estate value in 2015 (excluding any new developments after 2005) & $2,270.85$ \\
Depreciated value & 478.84 \\
Private domestic real estate value in 20I5 if the depreciation rate can be reduced by 10\% & $2,471.10$ \\
Depreciated value & 278.60 \\
Net value enhancement & $\mathbf{2 0 0 . 2 4}$ \\
\hline
\end{tabular}

durability plays a crucial role in achieving sustainable development. A 10 per cent reduction of the depreciation rate helps achieve a net saving of about 10 per cent GDP of the city in a decade. It is a substantial sum of wealth that our society has ignored for more than a century. Globally, it is hard to find any data on asset depreciation value, except those estimates for accounting purposes.

This paper emphasises more on economic analysis, but the social and environmental benefits of having more durable housing are tremendous. Furthermore, the ways of how to reduce depreciation rate have not been discussed here. These issues are left for further discussions and studies.

\section{References}

Atkinson, G., Dubourg, R., Hamilton, K., Munasinghe, M., Pearce, D. and Young, C. (1997) Measuring Sustainable Development: Macroeconomics and the Environment, Edward Elgar Publishing Ltd., UK.

Chinloy, P.T. (1977) 'Hedonic price and depreciation indexes for residential housing: a longitudinal approach', Journal of Urban Economics, 4, 469-482.

Hong Kong Government (2006) Hong Kong Fact Sheet: Population, Information Services Department, Hong Kong SAR Government, Hong Kong.

Hulten, C.R. and Wykoff, F.C. (1981) 'The estimation of economic depreciation using vintage asset prices — an application of the Box-Cox power transformation', Journal of Econometrics, 15, 367-396.

Jones, K. and Clements-Croome, D. (2004) Towards a Sustainable Urban Environment, in COBRA 2004 - The International Construction Research Conference of the Royal Institute of Chartered Surveyors, RICS Foundation and Leeds Metropolitan University, UK, 7-8th September, 2004.

Malpezzi, S., Ozanne, L. and Thibodeau, T.G. (1987) 'Microeconomic estimates of housing depreciation', Land Economics, 63(4), 372-385.

Pearce, A.R., DuBose, J.R. and Vanegas, J.A. (1996) Rehabilitation as a Strategy to Increase the Sustainability of the Built Environment, School of Civil and Environmental Engineering, Georgia Institute of Technology, USA.

Shilling, J.D., Sirmans, C.F. and Dombrow, J.F. (1991) 'Measuring depreciation in single-family rental and owneroccupied housing', Journal of Housing Economics, 1, 368-383.

Sirmans, G.S., Macperson, D.A. and Zietz, E.N. (2005) 'The composition of Hedonic pricing models', Journal of Real Estate Literature, 13(1), 3-43.

United Nations (1992) National Accounts Statistics: Main Aggregates and Detailed Tables 1990, United Nations, NY.

United Nations (2002) World Summit on Sustainable Development - What Was Achieved and the Way Forward, retrieved on 3rd January, 2005, at http://www/un.org/esa/sustdev/media/Brochure.pdf.

United Nations (2007) UN Statistics Division Homepage, retrieved on 18th April, 2007, at http://unstats.un.org/unsd/ sna1993/glossform.asp?getitem=616.

WCED (1987) Our Common Future, Oxford University Press, UK (The Bruntland definition of sustainability, World Commission on Environment and Development, United Nations).

Wykoff, F.C. (1989) 'Economic depreciation and the user cost of business-leased automobiles', in Jorgenson, D.W. and Landau, R. (eds) Technology and Capital Formation, MIT Press, Cambridge, London.

Yiu, C.Y. (2002) 'The effects of age housing prices in Hong Kong', PhD Thesis, Department of Real Estate and Construction, The University of Hong Kong, Hong Kong (Unpublished). 